Indian Journal of Research in Pharmacy and Biotechnology (IJRPB) ISSN: 2321-5674 (Print), 2320-3471 (Online)

CrossRef DOI: https://doi.org/10.31426/ijrpb Indexed in CAS and CABI, Impact Factor: 0.64

\title{
DESIGNING OF FORMULATION OF SUSTAIN RELEASE TABLET OF TACROLIMUS WITH COTRIMAXAZOLE
}

\author{
AMIT. S. SWARNKAR*, DR. DHARMENDRA AHUJA ${ }^{2}$ \\ ${ }^{1}$ Research Scholar, Department of Pharmaceutical Sciences, Faculty of Pharmaceutical Science \\ ${ }^{2}$ Research Supervisor, Department of Pharmaceutical Sciences, Faculty of Pharmaceutical Science \\ Jyothi Vidyapeeth Women's University, Jaipur (Rajasthan), India
}

Corresponding Author Email: $\quad$ Swarnkar3033@gmail.com

ABSTRACT

The tablet helps to achive

Keywords:

Tablet of

Tacrolimus with

Cotrimaxazole,
1. A single tablet for three medicines

2. A single tablet for three complications

3. Comparatively less medication after organ transplant

4. Reduces the chance of infection after organ transplant

5. Drug category: immunosuppressant and antibiotic

6. To reduce the frequency of drug intake

7. To reduce chance of drug - drug interaction

To do so following consideration is to be kept in mind during formulation

1. Tablet drug content should be potent to their action.

2. To reduce chance of drug -drug interaction

3. To increase bioavailability and effectivity

4. Selection of best combination of immunosuppressant with suitable antibiotic. 


\section{Indian Journal of Research in Pharmacy and Biotechnology (IJRPB) ISSN: 2321-5674 (Print), 2320-3471 (Online)}

CrossRef DOI: https://doi.org/10.31426/ijrpb Indexed in CAS and CABI, Impact Factor: 0.64

Introduction

The first successful kidney transplant was performed by Dr. Joseph Murray, a plastic surgeon, in 1952. Since that time, significant advances in transplant surgery and immunologic research led to longer lives for solid organ transplant recipients (SOTRs). Resultant improved quality of life led to increased demand for plastic and reconstructive surgery in SOTRs. One common indication for surgical management in SOTRs is squamous cell carcinoma, which presents more frequently and at more advanced stage in SOTRs. In 2012, over 28,000 organ transplants were performed in the United States. Long-term survival of solid organ transplant recipients (SOTRs) has increased dramatically due to advancements in surgical technology and immunosuppressive therapies. Bacteria are the leading cause of infections after solid organ transplantation. In recent years, a progressive growth in the incidence of multidrug-resistant (MDR) and extensively-drug-resistant (XDR) strains has been observed. While methicillin-resistant Staphylococcus aureus(MRSA) infection is declining in non-transplant and SOT patients worldwide, vancomycin-resistant enterococci, MDR/XDR Enterobacteriaceaeand
MDR/XDR non-fermenters are progressively growing as a cause of infection in solid organ transplant (SOT) patients and represent a global threat. As the antibiotics active against MDR bacteria have several limitationsfor their use, which include less clinical experience, higher incidence of adverse effects and less knowledge of the pharmacokinetics of the drug, and, in most cases, are only available for parenteral administration.Manufacturing of tablet and syrup are usual in pharmaceutical field, all most all times patient need to take many tablet for different reason at a time or at a gap of certain period. It is difficult in case of pediatric patient to give many tablets as they generally refuse to take such therapy.

Tablets are the most widely used dosage form because of its convenience in terms of selfadministration, compactness and ease in manufacturing. Tablet disintegration hasbeen considered asthe rate limiting step in faster drug release. Developing a solid oral dosage form in today'smarket can be challenging. There are many pressures to discover new entities and maximize the lifecycle of products while maintaining safety, costeffectiveness, and speed to market Tablets are almost certainly the most cost-effective. And 


\section{Indian Journal of Research in Pharmacy and Biotechnology (IJRPB)} ISSN: 2321-5674 (Print), 2320-3471 (Online)

CrossRef DOI: https://doi.org/10.31426/ijrpb Indexed in CAS and CABI, Impact Factor: 0.64

efficientform of dispensing medicines. Tablet provides a versatile, compact, robust and accurateplatform for drug delivery. While the functional versatility of the tablet as a dosage form has been appreciated for decades, the design versatility of the tablet has historically been underappreciated One of the approach to increase gastric residence time is by gastroreten.

$>$ Many times patient miss the drug dose to be taken due to work load or forgetness.

$>$ Due to busy schedule especially at the afternoon time, where they get hardly time for lunch.

$>$ Patient has to take number of drugs, when he suffers from fever, in such condition patient has to take a single drug and over.

> Tablet becomes economical to patient and even to manufacturer.

Here we have tried to make compatible formulation with each other such that drug release profile should reach to maximum in a controlled condition.
Various formulations have been developed and tried to incorporate combination of polymer so that the best formulation can be developed.

At least $90 \%$ of drug used to produce systemic effect are administered by oral route. Tablet are intended for oral administration, some are swallowed whole, some are being chewed, some are dissolved or dispersed in water before being and some are retained on mouth, where the active ingredients are liberated. Tablets are used for systemic effect drug delivery. For systemic use drug must be released from tablet that dissolve in fluid of mouth, stomach and intestine and then absorbed into systemic circulation by which it show its therapeutic effect.

Resultant improved quality of life led to increased demand for plastic and reconstructive surgery in SOTRs. One common indication for surgical management in SOTRs is squamous cell carcinoma, which presents more frequently and at more advanced stage in SOTRs. Few studies investigate outcomes of surgeries performed on SOTRs after transplantation. Case reports describe individual instances of surgery 


\section{Indian Journal of Research in Pharmacy and Biotechnology (IJRPB)} ISSN: 2321-5674 (Print), 2320-3471 (Online)

CrossRef DOI: https://doi.org/10.31426/ijrpb

Indexed in CAS and CABI, Impact Factor: 0.64

performed on SOTRs. Case series assessing safety of plastic surgery in SOTRs, including free flap reconstruction, found no definitive contraindication to performing these procedures in carefully selected SOTRs. In US a 2009 nationwide survey, $25 \%$ of responding plastic surgeons reported they performed plastic surgery procedures in SOTRs with an extremely low complication prevalence based on self-report.

Within transplant medicine, the risk of allograft rejection is one of the major hurdles that must be overcome. In recent years, there has been an increase in the survival rates of solid organ transplant recipients due to advancements in organ procurement, surgical methods, and immunosuppressive therapy. Despite this progress, transplanted organs still experience injury caused by immune and nonimmune related factors that include rejection due to infiltrating immune cells or antibodies against donor specific epitopes in the transplanted organ, viral infection, and drug toxicity due to the long-term use of immunosuppressive drugs. Part, if not the majority of this injury is caused by immune and non-immune related factors and can be avoided by the timely detection of such events in their early stage. Current diagnostic approaches lack the necessary sensitivity and selectivity required to accurately identify these events early enough so that the damage to the transplanted organ or "graft" can be avoided.

Early identification of allograft injury not only allows for timely intervention but can also be used for patient-specific customization of immunosuppressive drugs to optimize graft outcome. Understanding the correlation between their presence or lack thereof also offers insight into post-transplant graft monitoring. Early detection of rejection events in conjunction with intervention is therefore the key to the prevention of acute rejection and other subsequent injuries, which can occur within the first few years after transplantation. $^{2}$

\section{EXPERIMENTAL WORK}

\section{Pre-formulation Studies}

\subsection{Organoleptic properties:}

\subsubsection{Colour:}

A small quantity of active drug powder was taken in butter paper and viewed in well illuminated places

\subsubsection{Odour:}

Very less quantity of active drug powder was used and smelled to get the odour. 


\section{Indian Journal of Research in Pharmacy and Biotechnology (IJRPB)} ISSN: 2321-5674 (Print), 2320-3471 (Online)

CrossRef DOI: https://doi.org/10.31426/ijrpb Indexed in CAS and CABI, Impact Factor: 0.64

2. Characterization Study

\subsection{Peak identification by HPLC:}

For Tacrolimus: The HPLC assay was carried out using an Agilent Eclipse XDB-C8 column $(5 \mu \mathrm{m}, 4.6 \mathrm{~mm} \times 150$ $\mathrm{mm}$ ) where the column temperature was 50 and detection wavelength was $210 \mathrm{~nm}$, and the mobile phase was $50 \%$ acetonitrile and 50\% monobasic potassium phosphate buffer $(0.05$ mol.L-1),which contained $\quad 0.2 \%$ polyoxyethylene lauryl ether (Brij35) with $\mathrm{pH}$ adjusted to $3.0 \pm 0.1$ with phosphoric acid.The flow rate was 1.5 $\mathrm{mL}$ per minute. The test solution of tacrolimus was prepared with a mixture of water and acetonitrile(1:1),incubated for 3 hours at ambient temperature to allow the dynamic equilibrium of three stereoisomers of tacrolimus.

For sulphamethoxazole and trimethoprim: Preparation of Mobile Phase: Prepare, filtered and degassed mixture of buffer and Acetonitrile in the ratio of $30: 70 \mathrm{v} / \mathrm{v}$. Preparation of Standard solution: Accurately weighed and transferred about 50mg of sufamethoxazole and $10 \mathrm{mg}$ of Trimethoprim working standard into a $10 \mathrm{ml}$ volumetric flask add $2 \mathrm{ml}$ of mobile phase, sonicated for $15 \mathrm{~min}$ and make up to the mark with mobile phase. Preparation of Sample solution: Crush 20 tablets and transferred accurately weighed powder equivalent to $50 \mathrm{mg}$ of Sulfamethoxazole and $10 \mathrm{mg}$ of Trimethoprim into $10 \mathrm{ml}$ volumetric flask add $7 \mathrm{ml}$ of mobile phase sonicate for $20 \mathrm{~min}$ to dissolve and make up to the volume with mobile phase. Filter the solution through $0.45 \mu \mathrm{m}$ nylon filter. Transfer $0.1 \mathrm{ml}$ of above solution into $10 \mathrm{ml}$ volumetric flask and make up to the volume with mobile phase $(50 \mathrm{ppm}$ of sulphamethoxazole \& 10ppm of trimethoprim).

3. Procedure for evaluation of granules parameters

\subsection{Flow Properties:}

\subsubsection{Angle of repose:}

Angle of repose is an indicative of the frictional forces existing between the particles. It is defined as the maximum angle possible between the surface of the pile of powder and the horizontal plane. 


\section{Indian Journal of Research in Pharmacy and Biotechnology (IJRPB) ISSN: 2321-5674 (Print), 2320-3471 (Online)}

CrossRef DOI: https://doi.org/10.31426/ijrpb

Indexed in CAS and CABI, Impact Factor: 0.64

$$
\begin{gathered}
\operatorname{Tan} \theta=\mathrm{h} / \mathrm{r} \\
\theta=\tan ^{-1}(\mathrm{~h} / \mathrm{r})
\end{gathered}
$$

Where: $\theta=$ angle of repose, $\mathrm{h}=$ height of the heap of powder in $\mathrm{cm}, \mathrm{r}=$ radius.

Value of $\theta$ are rarely less than $20^{\circ}$ and values up to $40^{\circ}$ indicates good flow potential.

\section{Method}

A funnel was fixed at a particular height ' $h$ ' $\mathrm{cm}$ on a burette stand. A graph paper was placed below the funnel on the table. The given powder whose angle of repose is to be determined passed slowly through the funnel, until it forms a pile. Care is taken to see that the drug particles slip and roll over each other through the sides of the funnel. Further addition of the powder is stopped as soon as the pile touches the tip of the funnel. Circumference of the pile is drawn with pencil without disturbing the pile. The radius of the pile is noted as ' $\mathrm{r}$ ' $\mathrm{cm}$. Angle of repose $\theta$ of the granules is then calculated from the above formula.

\begin{tabular}{|l|c|}
\hline \multicolumn{1}{|c|}{ Flow properties } & Angle of repose \\
\hline Excellent & $25-30$ \\
\hline Good & $31-35$ \\
\hline Fair aid may hang up & $36-40$ \\
\hline $\begin{array}{l}\text { Poor must agate } \\
\text { Vibrate }\end{array}$ & $41-45$ \\
\hline Very poor & $46-55$ \\
\hline Very, very poor & $>66$ \\
\hline \multicolumn{2}{|c|}{ Table No. Flow properties and } \\
Corresponding Angle of repose.
\end{tabular}

\subsubsection{Bullk density $\left(\mathrm{p}_{\mathrm{b}}\right)$ :}

It is the ratio of total mass of powder to the bulk volume of powder. It was measured by pouring the weighed powder into a measuring cylinder and the volume was noted. It is expressed in $\mathrm{gm} / \mathrm{ml}$ and is given by;

$$
\mathrm{Pb}=\frac{\mathrm{M}}{\mathrm{V}_{\mathrm{b}}}
$$

Where: $\quad \mathrm{M}$ is mass of powder, $\mathrm{V}_{\mathrm{b}}$ is the Bulk volume of the powder.

\section{Method}

Accurately weighed quantities of the powders (5gm) were carefully poured into the graduated cylinder through a large funnel and the bulk volume was noted with and without taping. Bulk and tapped densities were calculated from the following formula, weight / untapped or initial volume and weight / tapped volume, respectively. 


\section{Indian Journal of Research in Pharmacy and Biotechnology (IJRPB) ISSN: 2321-5674 (Print), 2320-3471 (Online)}

CrossRef DOI: https://doi.org/10.31426/ijrpb

Indexed in CAS and CABI, Impact Factor: 0.64

\subsubsection{Taped density:}

The granules sample was poured gently through glass fumed into graduated measuring cylinder. Initial volume of powder was noted and the sample subjected to tapping (500, 750 or 1250 Tapping) until to further reduction in volume was noted or the percentage of difference in volume was not more than $2 \%$ Volume occupied the samples after tapping was recorded and tapped density was calculated using following formula.

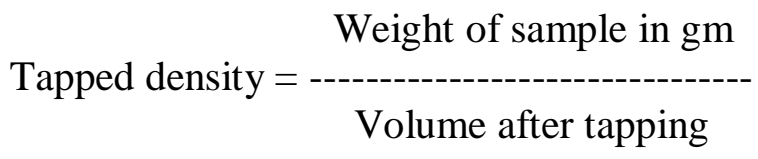

\subsubsection{Compressibilility:}

An important measure that can be obtained from bulk density determination is the percent compressibility, which is defined as:

$$
\mathrm{C}=\rho \mathrm{t}-\rho \mathrm{b} / \rho \mathrm{t} \times 1
$$

Where: $\rho b=$ bulk density

$\rho t=$ tapped bulk density

In theory, the less compressible a material means, the more flow able it is. A material having a $\mathrm{C}$ value of less than $20 \%$ is defined as free-flowing powder.

\subsubsection{Hauser's Ratio:}

It is the ratio of bulk volume to tapped volume or tapped density to bulk density.

Hausner's Ratio $=\rho t / \rho b$

Where: $\rho b=$ bulk density

$\rho t=$ tapped bulk density

\begin{tabular}{|c|c|}
\hline $\begin{array}{c}\text { Limits of Hausner's } \\
\text { Ratio }\end{array}$ & Category \\
\hline $1.2-1.3$ & Excellent \\
\hline $1.3-1.4$ & Good \\
\hline $1.4-1.5$ & Fair \\
\hline $1.5-1.6$ & Poor \\
\hline
\end{tabular}

Table no. 2: Scale of Flowability by

Hausner's Ratio

4. Preparation of stock solution for

standard calibration curve

\subsection{Preparation of stock solution for \\ Tacrolimus :}

$1 \mathrm{mg}$ of Tacrolimus was dissolved in $10 \mathrm{~mL}$ of methonolic phosphate buffer $\mathrm{pH} 6.8$ to get 100 $\mu \mathrm{g} / \mathrm{mL}$ solutions.

\subsubsection{Development of Standard}

\section{Calibration Curve of}

\section{Tacrolimus}

From the above stock solution $1 \mathrm{ml}, 2 \mathrm{ml}, 3 \mathrm{ml}$, $4 \mathrm{ml}, 5 \mathrm{ml}$ and $6 \mathrm{ml}$ were pipetted out and made up to $10 \mathrm{ml}$ by using distilled water in standard flasks to produce 10, 20, 30, 40, 50 and $60 \mu \mathrm{g} / \mathrm{ml}$ respectively. The absorbance 


\section{Indian Journal of Research in Pharmacy and Biotechnology (IJRPB) ISSN: 2321-5674 (Print), 2320-3471 (Online)}

CrossRef DOI: https://doi.org/10.31426/ijrpb

Indexed in CAS and CABI, Impact Factor: 0.64

was measured at $297 \mathrm{~nm}$ in a UV spectrophotometer using distilled water as blank. The data's were tabulated. The concentration was plotted against absorbance.

\subsection{Preparation of stock solution of sulphamethoxazole:}

Solution of $1000 \mu \mathrm{g} . \mathrm{mL}-1$ sulfamethoxazole was prepared by dissolving accurate weighted $0.100 \mathrm{~g}$ of pure drug in $10 \mathrm{~mL}$ of $0.4 \mathrm{M} \mathrm{HCl}$ and further diluted to the mark in volumetric flask $100 \mathrm{~mL}$ with distilled water and stored in a $\operatorname{cool}\left(<25^{\circ} \mathrm{C}\right)$ and dark place.

\subsubsection{Development of Standard}

\section{Calibration Curve of}

\section{sulphamethoxazole:}

The concentration of sulfamethoxazole (SMX) in calibration curve was $750 \mathrm{ng} / \mathrm{mL}$, $2080 \mathrm{ng} / \mathrm{mL}, 3330 \mathrm{ng} / \mathrm{mL}, 4170 \mathrm{ng} / \mathrm{mL}, 5$ $\mu \mathrm{g} / \mathrm{mL}, 5833 \mathrm{ng} / \mathrm{mL}, 6670 \mathrm{ng} / \mathrm{mL}$ for SMX.

\subsection{Preparation of stock solution of trimethoprim:}

Primary stock solutions consisted of trimethoprim $(0.32 \mathrm{mg} / \mathrm{mL})$ were prepared in methanol. Trimethoprim stock solution was further diluted with mobile phase to obtain different concentration.

\subsubsection{Development of Standard Calibration Curve of trimethoprim:}

The concentration of trimethoprim (TMP) in calibration curve was $150 \mathrm{ng} / \mathrm{mL}, 420 \mathrm{ng} / \mathrm{mL}$, $670 \mathrm{ng} / \mathrm{mL}, 830 \mathrm{ng} / \mathrm{mL}, 1000 \mathrm{ng} / \mathrm{mL}, 1170$ $\mathrm{ng} / \mathrm{mL}, 1330 \mathrm{ng} / \mathrm{mL}$ for TMP.

The dilution was analyzed for absorbance at $297 \mathrm{~nm}$ using a UV-visible spectrophotometer (shimandzu, JAPAN). The calibration curve was obtained in accordance with BeerLambert law.

\section{Preparation of sustain release Tablets by wet granulation Method}

The sustain release tablets were prepared by conventional wet granulation technique. The composition with respect to polymer combination was selected on the basis of trial preparation of tablets. In each formulation, the amount of the total weight of a tablet is about $1000 \mathrm{mg}$. A batch of 50 tablets was prepared with each formula. The ingredients were passed through a 60 -mesh sieve. A blend of all ingredients except glidant and lubricant was mixed, a particular attention had been given to 


\section{Indian Journal of Research in Pharmacy and Biotechnology (IJRPB) ISSN: 2321-5674 (Print), 2320-3471 (Online)}

CrossRef DOI: https://doi.org/10.31426/ijrpb Indexed in CAS and CABI, Impact Factor: 0.64

ensure thorough mixing and phase homogenization. Granulation was done manually with a solution of water. The wet masses were passed through a 12 mesh sieve and the wet granules produced were first air dried for $10 \mathrm{~min}$ and finally at $45-50^{\circ}$ in a tray drier for $2 \mathrm{~h}$. The dried granules were sized by a 16-mesh sieve and after lubrication with magnesium stearate. Compression was carried out using $8 \mathrm{~mm}$ flat faced circular punches into tablets on an multi station rotary tablet compression machine at a constant compression force. Just before compression, the surfaces of the die and punches were lubricated with magnesium stearate. All the tablets were stored in airtight close containers for further tests.

\section{Procedure For Evaluation Of Tablets}

The tablets were compressed using $8 \mathrm{~mm}$ diameter, round, biconcave punches on a multistation rotary tablet machine. The tablet weight was kept about $1000 \mathrm{mg}$ and hardness between $6-7 \mathrm{~kg} / \mathrm{cm}^{2}$. Other parameters like size, thickness, shape, hardness, friability, weight variation, wetting time were carried out.

\subsection{Thickness and Shape:}

Size (diameter) and thickness was measured using Vernier Caliper.

\section{Method}

Ten tablets from each formulation were selected and their crown thickness was measured with a Vernier Calliper. Shapes of the tablets were observed.

\subsection{Hardness:}

Tablets require a certain amount of strength or hardness to withstand mechanical shocks of handling in manufacturing, packing and shipping.

\section{Method}

The Monsanto hardness tester consists of a barrel containing a compressible spring held between two plungers. The lower plunger is placed in contact with the tablet and zero reading is taken. The upper plunger is then forced against a spring by turning threaded bolt until the tablets break. As the spring is compressed, a pointer rides along a gauge in the barrel to indicate the force. The force of break was recorded and zero force reading is deducted from it. 


\section{Indian Journal of Research in Pharmacy and Biotechnology (IJRPB) ISSN: 2321-5674 (Print), 2320-3471 (Online)}

\subsection{Friability:}

Tablets were tested for friability using Electrolab Friabilator. This is important to know the mechanical strength of the tablet while handling.

\section{Method}

Twenty tablets were weighed initially and transferred to the Friabilator. The instrument was set to $25 \mathrm{rpm}$ for 100 rotations. The resulting tablets were reweighed and percentage loss was calculated using the formula.

$\mathrm{F}=\quad$ (Initial weight - Final weight $) \times 100$

\subsection{Weight Variation:}

Weight variation was determined to know whether different batches of tablets have uniformity.

\section{Method}

Weighed 20 tablets individually, calculated the average weight, and compared the individual tablet weights to the average. The tablets meet the test if not more than two tablets are outside the percentage limit and none of the tablet differs by more than two times the percentage limit. The weight variation tolerance for uncoated tablets differs depending on average weight of the tablets.

\subsection{Disintegration Test:}

The disintegration time was measured using a disintegration apparatus. For this purpose, 6 tablets were filled in vessel containing solvent or water or simulated saliva fluid. The tablet was carefully put in the center of the vessel and the time for the tablet to completely disintegrate into fine particles was noted in respective rotation.

\subsection{In Vitro Dissolution Study}

The release rate Tacrolimus, sulphamethoxazole and trimethoprim from sustain release dissolving tablets was determined using United State Pharmacopoeia (USP) XXIV dissolution testing apparatus II (paddle method).The dissolution test was performed using $900 \mathrm{ml}$ of $6.8 \mathrm{pH}$ phosphate buffer, at $37 \pm 0.50 \mathrm{C}$ and $50 \mathrm{rpm}$. A sample $(10 \mathrm{~mL})$ of the solution was withdrawn from the dissolution apparatus at 2, 4, 6, 8, 10, 12 hr. The samples were replaced with fresh dissolution medium of same quantity. The 


\section{Indian Journal of Research in Pharmacy and Biotechnology (IJRPB) ISSN: 2321-5674 (Print), 2320-3471 (Online)}

CrossRef DOI: https://doi.org/10.31426/ijrpb

Indexed in CAS and CABI, Impact Factor: 0.64

samples were filtered through a Watman filter paper. Absorbance of these solutions was measured at $297 \mathrm{~nm}, 259 \mathrm{~nm}, 237.6 \mathrm{~nm}$ respectively, using a Shimadzu UV1601UV/Visible beam spectrophotometer.

Cumulative percentage of drug release was calculated using an equation obtained from a standard curve.

\subsection{Drug Content: (Procedure for} determining Tacrolimus, sulphamethoxazole and trimethoprim in tablet formulation)

\section{Tablet Stock Solution:}

Twenty tablets were accurately weighed and powdered in a mortar. An amount of powder equivalent to the weight of one quarter of a tablet was mixed with $35 \mathrm{ml}$ of ethanol in $100 \mathrm{ml}$ - calibrated flasks. The mixture was then sonicated for 15 minutes on an ultrasonic bath and subsequently made up to volume with ethanol, filtered through a Whatman No. 1 filter paper and the filtrate used for preparation of the tablet assay solution.

\section{Tablet Assay Solutions:}

The tablet stock solution buffered to $\mathrm{pH} 4.5$ and ethanol were added to produce an assay solution equivalent to sulphamethoxazole 25 $\mu \mathrm{gml}-1$ and trimethoprim $5 \mu \mathrm{gml}-1$. The D1curve of the solutions $(n=5)$ were obtained and sulphamethoxazole and trimethoprim determined as described above.

\section{RESULTS AND DISCUSSION}

1. Preformulation studies for Tacrolimus, sulphamethoxazole and trimethoprim

\subsection{Organoleptics properties:}

The test was performed as per procedure given in material and method. The result is illustrated in following table.

\begin{tabular}{|l|c|l|l|}
\hline Test & $\begin{array}{c}\text { Tacroli } \\
\text { mus }\end{array}$ & $\begin{array}{l}\text { Sulphametho } \\
\text { xazole }\end{array}$ & $\begin{array}{l}\text { Trimetho } \\
\text { prim }\end{array}$ \\
\hline $\begin{array}{l}\text { Colo } \\
\text { ur }\end{array}$ & $\begin{array}{l}\text { White } \\
\text { powder }\end{array}$ & $\begin{array}{l}\text { White } \\
\text { slightly off } \\
\text { white } \\
\text { crystalline } \\
\text { powder }\end{array}$ & $\begin{array}{l}\text { White to } \\
\text { yellow } \\
\text { powder }\end{array}$ \\
\hline $\begin{array}{l}\text { Odou } \\
\text { r }\end{array}$ & $\begin{array}{c}\text { Odourle } \\
\text { ss }\end{array}$ & odourless & odourless \\
\hline $\begin{array}{l}\text { Melti } \\
\text { ng } \\
\text { point }\end{array}$ & $\begin{array}{c}169^{\circ} \mathrm{C}- \\
172^{\circ} \mathrm{C}\end{array}$ & $167-169^{\circ} \mathrm{C}$ & $199-203^{\circ} \mathrm{C}$ \\
\hline
\end{tabular}

Table No.3: Test and Observation of Sulphamethoxazole, trimethoprim and tacrolimus. 


\section{Indian Journal of Research in Pharmacy and Biotechnology (IJRPB) ISSN: 2321-5674 (Print), 2320-3471 (Online)}

CrossRef DOI: https://doi.org/10.31426/ijrpb Indexed in CAS and CABI, Impact Factor: 0.64

2. Characterization study by HPLC FOR PEAK IDENTIFICATION by HPLC TACROLIMUS

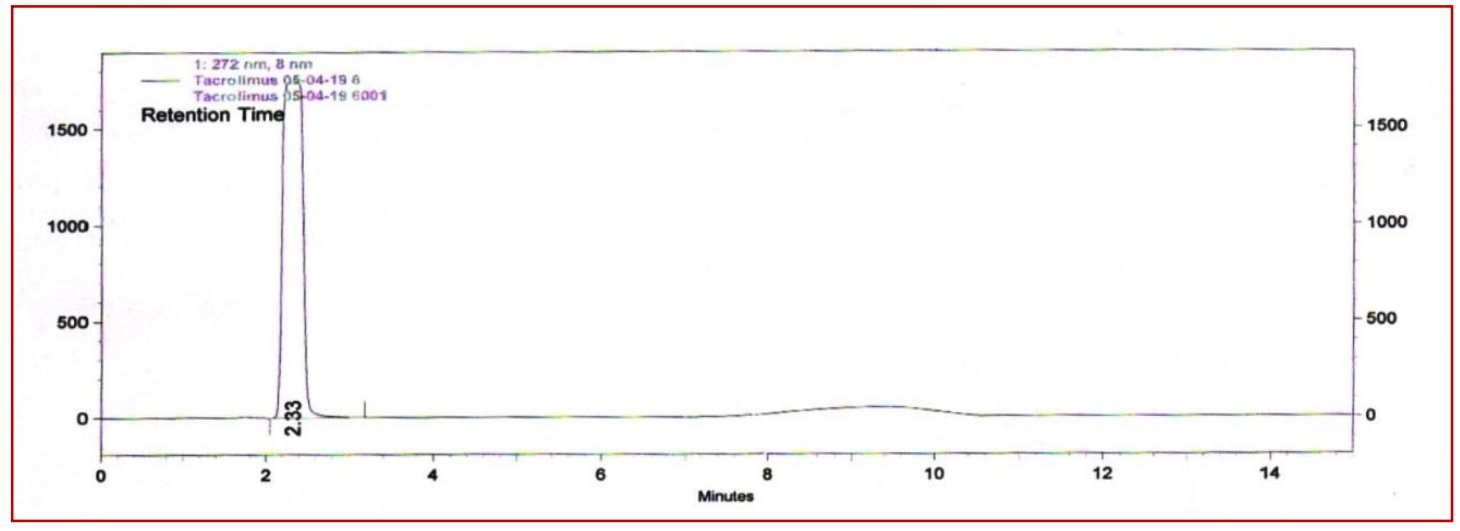

Figure No.1:Peak of tacrolimus by HPLC

TACROLIMUS AND SULPHAMETHOXAZOLE

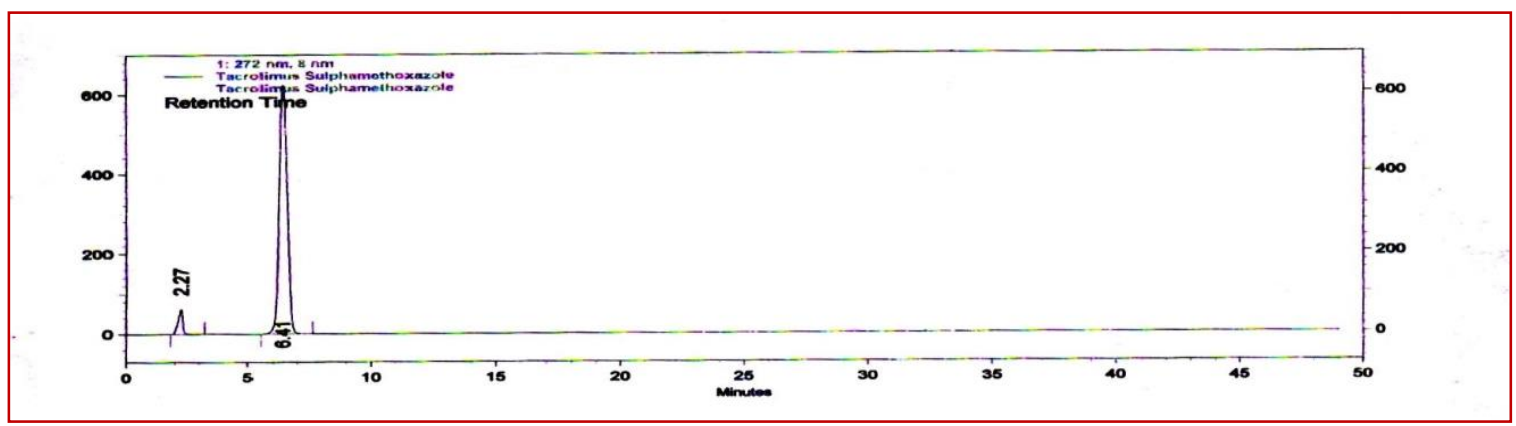

Figure No.2 : Peak of tacrolimus and sulphamethoxazole by HPLC

\section{TACROLIMUS and TRIMETHOPRIM}

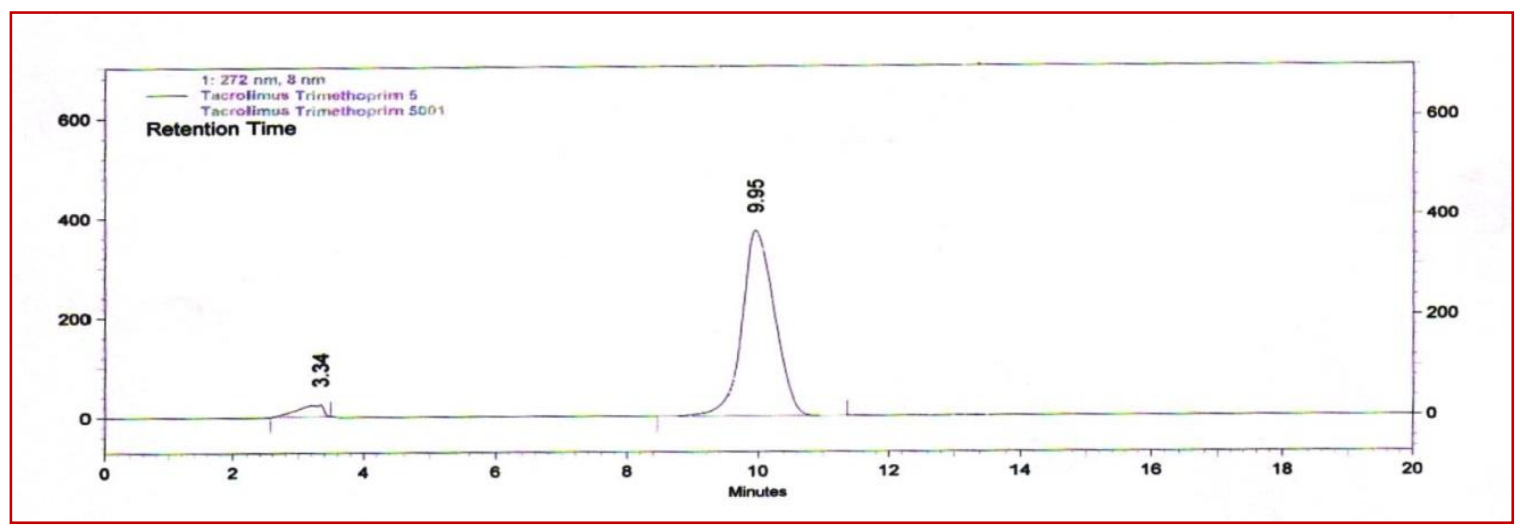

Figure No.3 : Pak of tacrolimus and trimethoprim by HPLC 


\section{Indian Journal of Research in Pharmacy and Biotechnology (IJRPB) ISSN: 2321-5674 (Print), 2320-3471 (Online)}

CrossRef DOI: https://doi.org/10.31426/ijrpb Indexed in CAS and CABI, Impact Factor: 0.64

\section{TACROLIMUS, SULPHAMETHOXAZOLE and TRIMETHOPRIM}

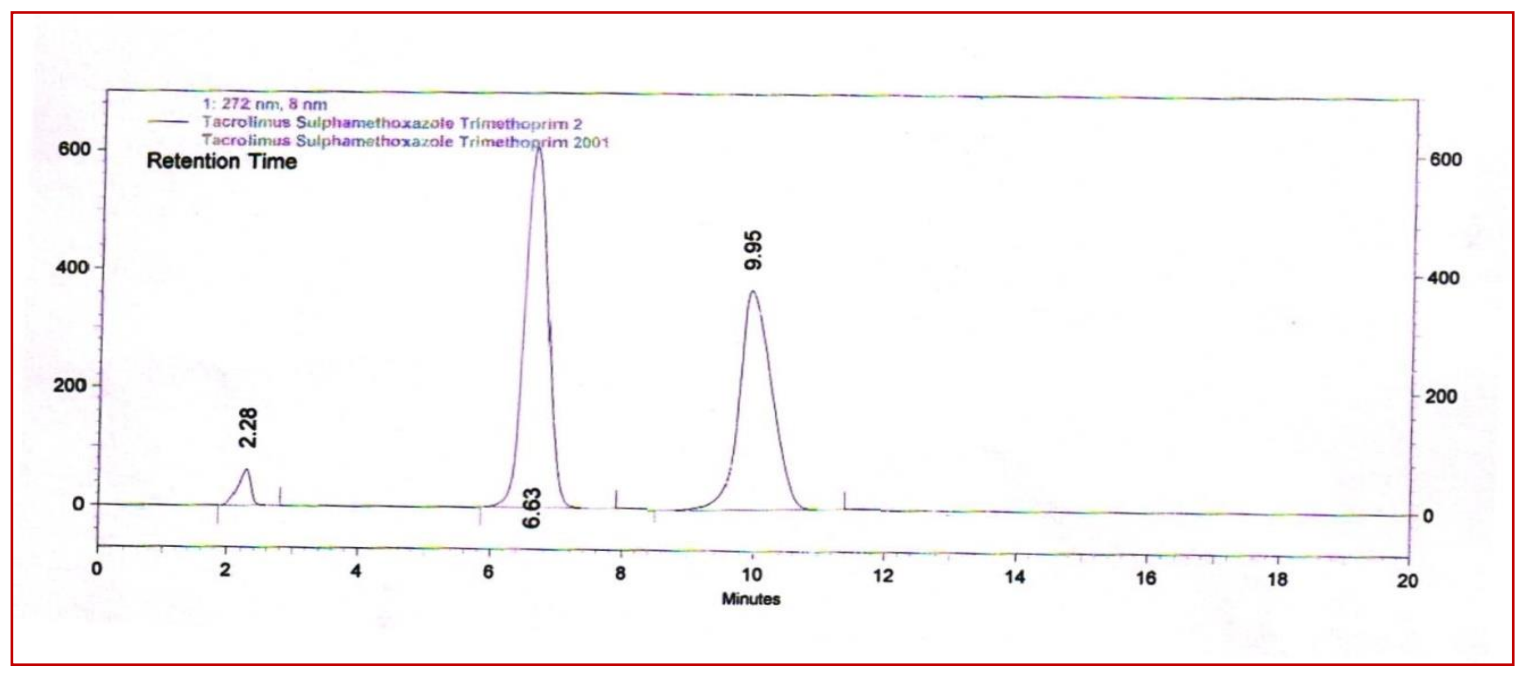

Figure No.4 : Peak of tacrolimus, sulphamethoxazole and trimethoprim by HPLC

3. Procedure For Evaluation Of Granules Parameter

\begin{tabular}{|c|c|c|c|c|c|}
\hline Batch & $\begin{array}{c}\text { Angle of } \\
\text { Repose }(\boldsymbol{\theta})\end{array}$ & $\begin{array}{c}\text { Bulk Density } \\
(\mathbf{g} / \mathbf{c c})\end{array}$ & $\begin{array}{c}\text { Tapped Density } \\
(\mathbf{g} / \mathbf{c c})\end{array}$ & Compressibility \% & $\begin{array}{c}\text { Hausner's } \\
\text { Ratio }\end{array}$ \\
\hline F1 & $26.0 \pm 0.01$ & $0.65 \pm 0.02$ & $0.73 \pm 0.03$ & $23.60 \pm 1.25$ & $1.32 \pm 0.03$ \\
\hline F2 & $29.7 \pm 0.03$ & $0.59 \pm 0.03$ & $0.79 \pm 0.03$ & $25.22 \pm 1.54$ & $1.34 \pm 0.03$ \\
\hline F3 & $25.1 \pm 0.04$ & $0.48 \pm 0.03$ & $0.78 \pm 0.04$ & $23.61 \pm 1.32$ & $1.34 \pm 0.02$ \\
\hline G4 & $26.3 \pm 0.04$ & $0.53 \pm 0.04$ & $0.70 \pm 0.02$ & $20.00 \pm 1.54$ & $1.32 \pm 0.03$ \\
\hline G5 & $27.5 \pm 0.03$ & $0.46 \pm 0.01$ & $0.71 \pm 0.03$ & $19.42 \pm 1.62$ & $1.25 \pm 0.02$ \\
\hline G6 & $30.5 \pm 0.05$ & $0.52 \pm 0.04$ & $0.67 \pm 0.03$ & $21.57 \pm 1.52$ & $1.29 \pm 0.03$ \\
\hline H7 & $26.5 \pm 0.01$ & $0.63 \pm 0.03$ & $0.57 \pm 0.04$ & $20.64 \pm 1.24$ & $1.22 \pm 0.02$ \\
\hline H8 & $27.4 \pm 0.02$ & $0.61 \pm 0.04$ & $0.68 \pm 0.03$ & $21.12 \pm 1.45$ & $1.24 \pm 0.01$ \\
\hline H9 & $29.7 \pm 0.03$ & $0.59 \pm 0.03$ & $0.79 \pm 0.03$ & $25.22 \pm 1.54$ & $1.34 \pm 0.03$ \\
\hline
\end{tabular}

Table No. 4: Pre-compression parameters of all formulation. (Mean \pm SD) 


\section{Indian Journal of Research in Pharmacy and Biotechnology (IJRPB) ISSN: 2321-5674 (Print), 2320-3471 (Online)}

CrossRef DOI: https://doi.org/10.31426/ijrpb Indexed in CAS and CABI, Impact Factor: 0.64

\section{ESTIMATION OF TACROLIMUS BY UV SPECTROSCOPY STANDARD CALIBRATION CURVE OF TACROLIMUS}

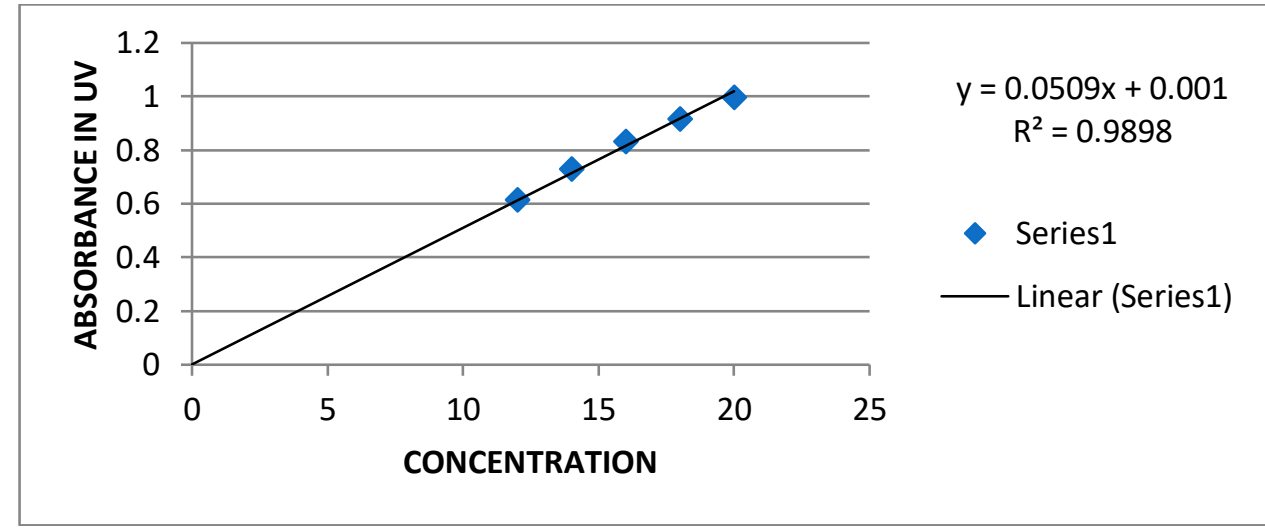

FigureNo.5 Standard calibration curve of Tacrolimus

\section{STANDARD CALIBRATION CURVE OF SULPHAMETHOXAZOLE}

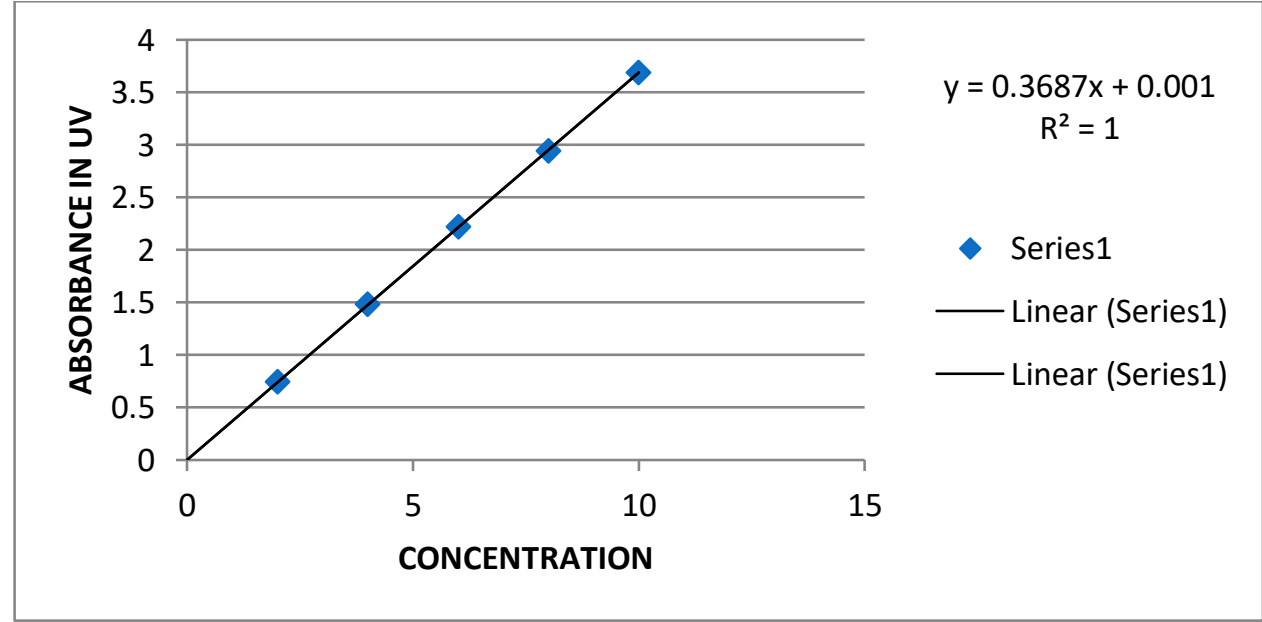

Figure No.6 Standard calibration curve of Sulphamethoxazole 


\section{Indian Journal of Research in Pharmacy and Biotechnology (IJRPB) ISSN: 2321-5674 (Print), 2320-3471 (Online)}

CrossRef DOI: https://doi.org/10.31426/ijrpb Indexed in CAS and CABI, Impact Factor: 0.64

STANDARD CALIBRATION CURVE OF TRIMETHOPRIM

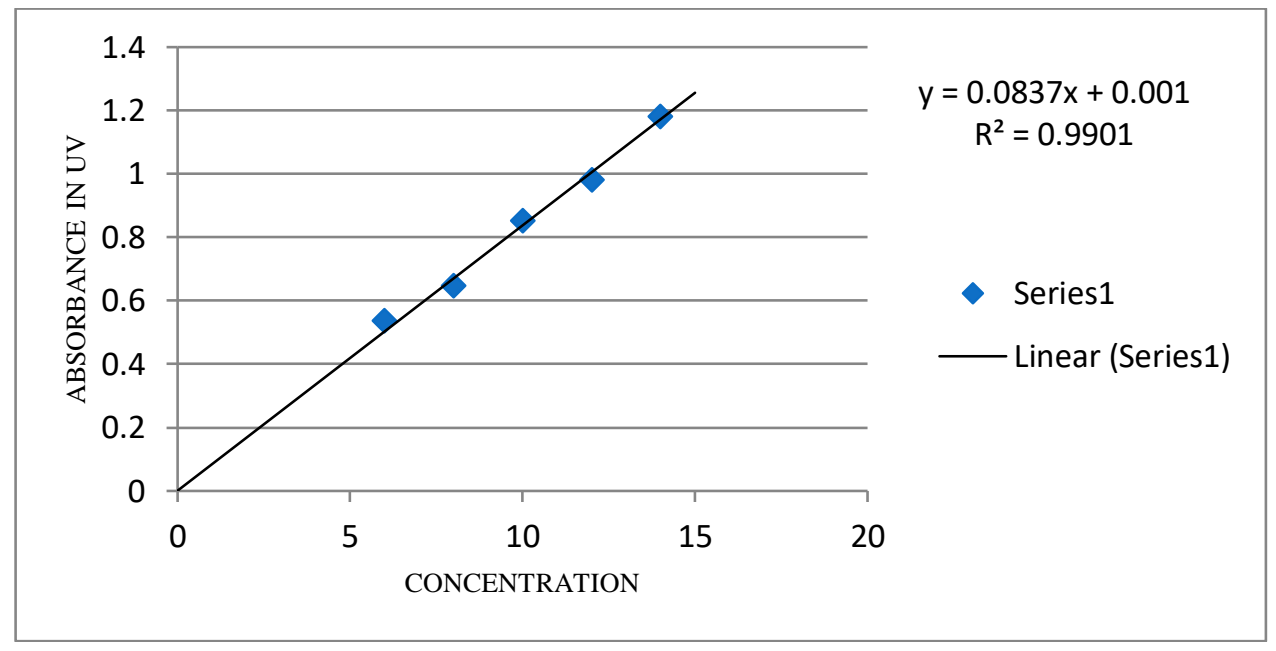

Figure No.7 Standard calibration curve of Trimethoprim

5. Preparation Of Sustain Release Tablet By Wet Granulation Method And Formulla:

\begin{tabular}{|c|c|c|c|c|c|c|c|c|c|c|}
\hline Ingredient & $\begin{array}{c}\text { Formulation } \\
\text { code }\end{array}$ & F1 & F2 & F3 & G4 & G5 & G6 & H7 & H8 & H9 \\
\hline Tacrolimus & & 10 & 10 & 10 & 10 & 10 & 10 & 10 & 10 & 10 \\
\hline trimethoprim & & 160 & 160 & 160 & 160 & 160 & 160 & 160 & 160 & 160 \\
\hline Sulphamethoxazole & & 800 & 800 & 800 & 800 & 800 & 800 & 800 & 800 & 800 \\
\hline Eudrogitrspo & \multirow{2}{*}{$\mathbf{F}$} & 7.5 & 10 & 5 & - & - & - & - & - & - \\
\hline PVP & & 12.5 & 10 & 20 & - & - & - & - & - & -- \\
\hline Gum copal & \multirow{2}{*}{ G } & - & - & - & 5 & 9.5 & 6 & - & - & - \\
\hline Bean gum & & - & - & - & 15 & 10.5 & 14 & - & - & - \\
\hline Gum damar & \multirow{2}{*}{$\mathbf{H}$} & - & - & - & - & - & - & 9 & 12.5 & 6 \\
\hline Guar gum & & - & - & - & - & - & - & 68.9 & 56 & 78 \\
\hline Mg. stearate & & 4 & 4 & 4 & 4 & 4 & 4 & 4 & 4 & 4 \\
\hline Starch I.P & & 29.75 & 35 & 35 & 29.75 & 35 & 35 & 29.75 & 35 & 35 \\
\hline Talcum & & 4 & 4 & 4 & 4 & 4 & 4 & 4 & 4 & 4 \\
\hline Sodium saccharine & & 4 & 4 & 4 & 4 & 4 & 4 & 4 & 4 & 4 \\
\hline Total & & 1042.1 & 1037 & 1042 & 1031.75 & 1037 & 1037 & 1089.65 & 1085.5 & 1101 \\
\hline
\end{tabular}

Table No. 5: Formulation of sustain release tablets of Tacrolimus and Cotrimaxazole 


\section{Indian Journal of Research in Pharmacy and Biotechnology (IJRPB) ISSN: 2321-5674 (Print), 2320-3471 (Online)}

CrossRef DOI: https://doi.org/10.31426/ijrpb Indexed in CAS and CABI, Impact Factor: 0.64

6. Evaluation of sustain release tablet of Tacrolimus, Sulphamethoxazole and Trimethoprim

\begin{tabular}{|c|c|c|c|c|}
\hline Batch & Thickness $(\mathbf{m m})$ & $\begin{array}{c}\text { Hardness } \\
\left(\mathbf{k g} / \mathbf{c m}^{\mathbf{2}}\right)\end{array}$ & $\begin{array}{c}\text { Friability } \\
(\mathbf{\%} \mathbf{w} \mathbf{w})\end{array}$ & Weight variation \\
\hline F1 & 4.36 & 8.45 & 0.396 & 1040 \\
\hline F3 & 4.42 & 8.67 & 0.387 & 1038 \\
\hline G4 & 4.40 & 8.45 & 0.390 & 1041 \\
\hline G5 & 4.54 & 7.95 & 0.354 & 1030 \\
\hline G6 & 4.55 & 7.96 & 0.327 & 1038 \\
\hline H7 & 4.57 & 7.84 & 0.312 & 1036 \\
\hline H8 & 4.61 & 8.84 & 0.198 & 1090 \\
\hline H9 & 4.59 & 8.77 & 0.210 & 1100 \\
\hline $\begin{array}{c}\text { Marketed tablet of Tacrolimus } \\
\text { (Macpod, from Macleods) }\end{array}$ & 5.60 & 8.78 & 0.275 & 1234 \\
\hline $\begin{array}{c}\text { Marketed tablet of } \\
\text { Sulphamethoxazole(P-125, Apex lab } \\
\text { Pvt Ltd.) }\end{array}$ & 4.89 & 8.24 & 0.264 & 1143 \\
\hline
\end{tabular}

Table No.6: Evaluation of sustain release tablet of Tacrolimus, Sulphamethoxazole and trimethoprim

6.1. Percentage Drug Release Of Tacrolimus At 260 NM And Sulphamethoxazole At 248 NM And Trimethoprim At 237.6 NM

\begin{tabular}{|c|c|c|c|c|}
\hline Sr. no & batches & $\begin{array}{c}\text { \% drug content for } \\
\text { Tacrolimus }\end{array}$ & $\begin{array}{c}\text { \% drug content for } \\
\text { Sulphamethoxazole }\end{array}$ & $\begin{array}{c}\% \text { drug content for } \\
\text { Trimethoprim }\end{array}$ \\
\hline 1 & F1 & 75.6 & 77.6 & $76.5 \%$ \\
\hline 2 & F2 & 80.28 & 66.8 & $57.6 \%$ \\
\hline 3 & F3 & 90.21 & 65.97 & $66.76 \%$ \\
\hline 4 & G4 & 97.38 & 96.3 & $90.37 \%$ \\
\hline 5 & G5 & 68.04 & 68.4 & $67.14 \%$ \\
\hline 6 & G6 & 74.43 & 83.5 & $87.37 \%$ \\
\hline 7 & H7 & 90.27 & 80.82 & $81.43 \%$ \\
\hline 8 & H8 & 87.46 & 78.26 & $74.64 \%$ \\
\hline 9 & H9 & 88.47 & 75.8 & $92.71 \%$ \\
\hline 10 & $\begin{array}{c}\text { Marketed tablet } \\
\text { (indivisually) }\end{array}$ & 92.73 & 91.97 & \\
\hline
\end{tabular}

Table No. 7: Percentage drug release of Tacrolimus at $260 \mathrm{~nm}$ and Sulphamethoxazole at 248 $\mathrm{nm}$ and trimethoprim at $237.6 \mathrm{~nm}$ 


\section{Indian Journal of Research in Pharmacy and Biotechnology (IJRPB) ISSN: 2321-5674 (Print), 2320-3471 (Online)}

CrossRef DOI: https://doi.org/10.31426/ijrpb Indexed in CAS and CABI, Impact Factor: 0.64

IN - VITRO DISSOLUTION PLOT OF TACROLIMUS

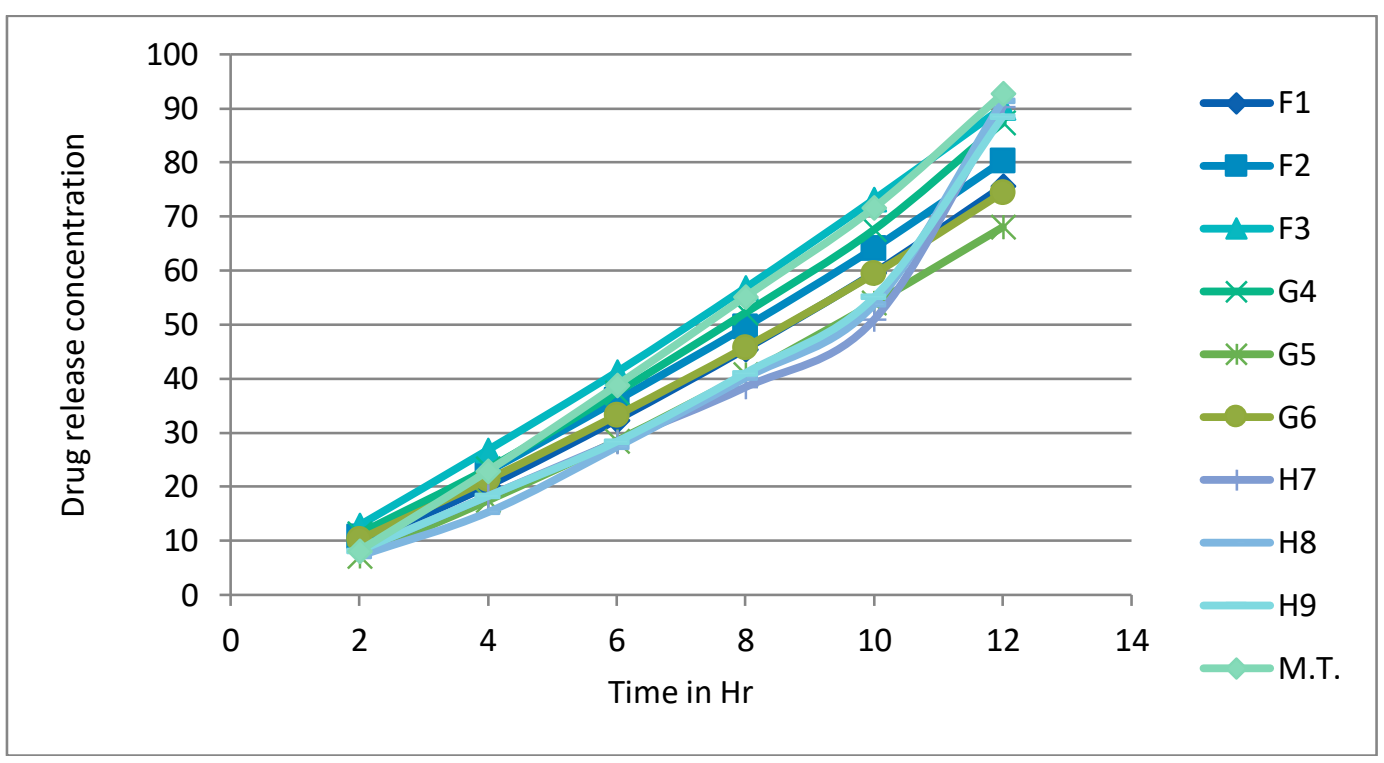

Figure No.8 In -vitro dissolution plot of Tacrolimus

IN-VITRO DISSOLUTION PLOT OF SULPHAMETHOXAZOLE

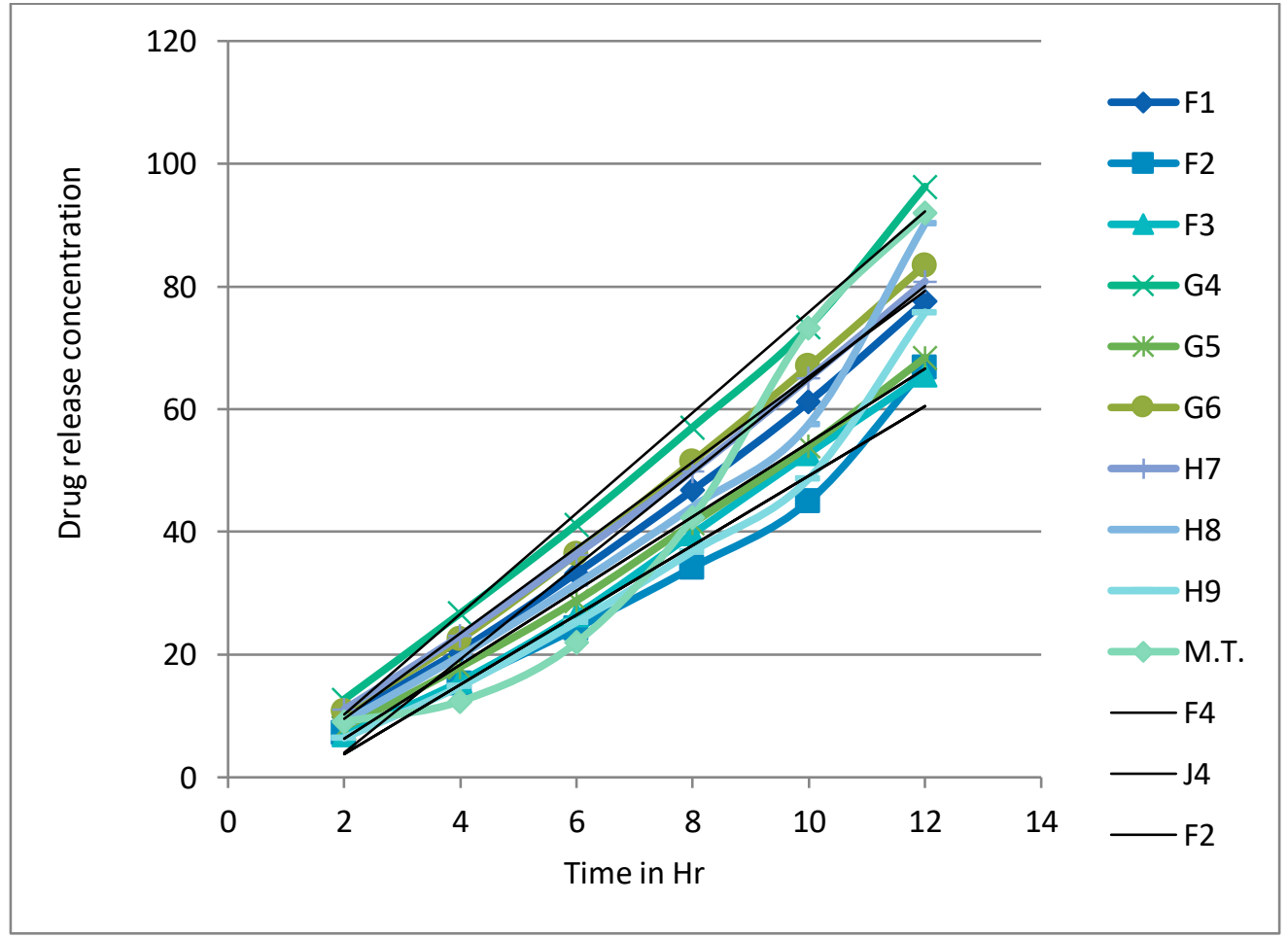

Figure No.9 In-vitro dissolution plot of sulphamethoxazole 


\section{Indian Journal of Research in Pharmacy and Biotechnology (IJRPB) ISSN: 2321-5674 (Print), 2320-3471 (Online)}

CrossRef DOI: https://doi.org/10.31426/ijrpb Indexed in CAS and CABI, Impact Factor: 0.64

\section{IN-VITRO DISSOLUTION PLOT OF TRIMETHOPRIM}

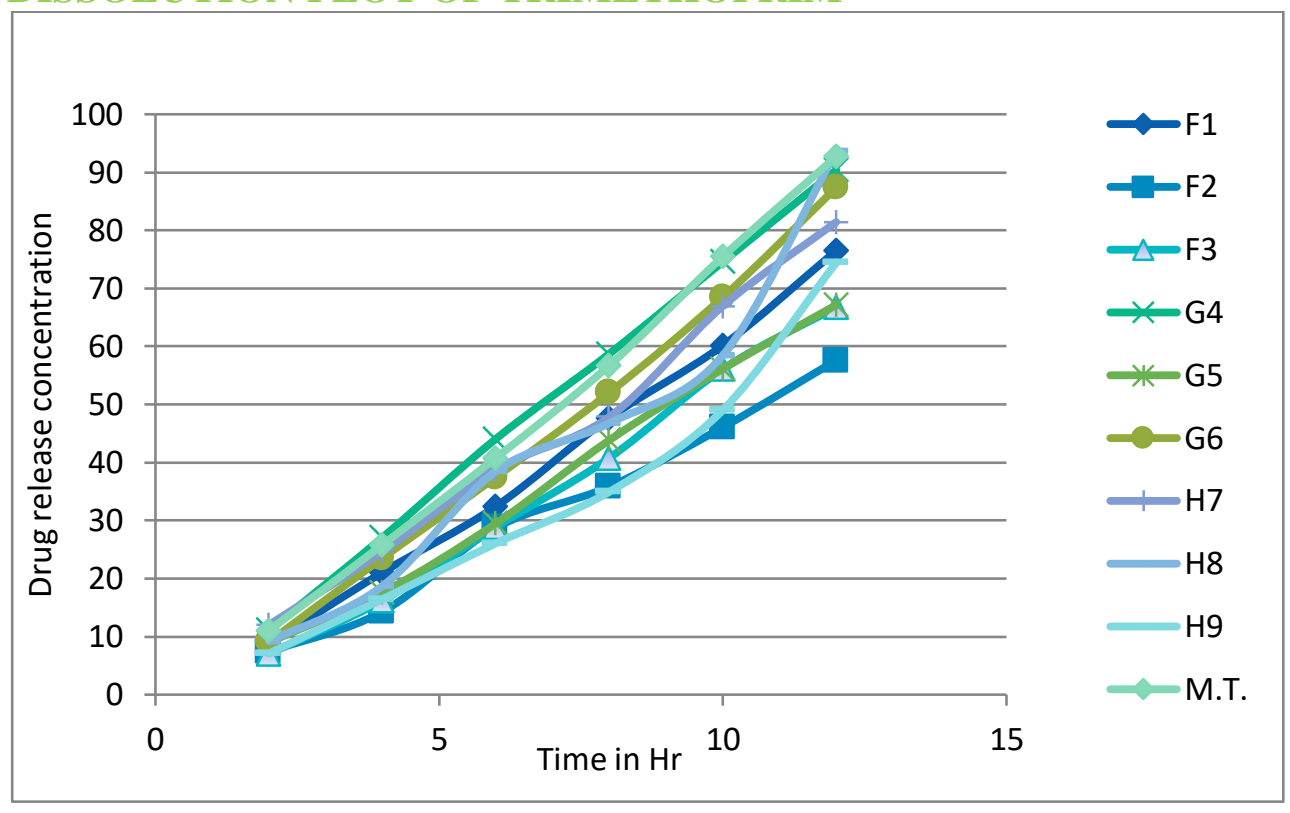

Figure No.10 In-vitro dissolution plot of trimethoprim

\section{CONCLUSION}

In present study, different polymers were used in combination so that good results can be obtained by prolonging the disintegrate time from $8-12 \mathrm{hrs}$, so that the drug can be absorbed in upper GIT. The batch F4 is found to be best batch producing $97.38 \%$ and $96.3 \%$, $90.37 \%$ of Tacrolimus, Sulphamethoxazole and Trimethoprim respectively by giving best time. In addition, it was found that formulation-containing combination of crossgum copal and bean gum gives a good result as compared to other combination.

There were no incompatibility found between drugs, polymer and excipient.The present study indicates that the oral sustained release tablets of Tacrolimus and co-trimaxazole provides a better option for development of a once-daily formulation of the drug. The analyst was found to be success in combining costly polymer with economical polymer.

\section{SUMMARY}

Many pharmaceutical dosages are administered in the form of pills, granules and liquid. Generally, the pills, which include tablet and capsule, are able to retain their shape under moderate pressure. However, some patient, particularly pediatric and 


\section{Indian Journal of Research in Pharmacy and Biotechnology (IJRPB) ISSN: 2321-5674 (Print), 2320-3471 (Online)}

CrossRef DOI: https://doi.org/10.31426/ijrpb Indexed in CAS and CABI, Impact Factor: 0.64

geriatric patient, has tendency to miss the solid dosage forms.

One of the primary objective in developing the sustain release tablet was to identify and satisfy an unmet need of general and specific population and to improve compliance and dosing ease for the patient. This system allows children, elderly and the general population to take their medications discretely wherever and whenever needed, satisfying the need of avoiding multiple dose.

Thus sustain release drug delivery system are rapidly gaining interest in the pharmaceutical industry. Preparation of sustain release tablet of Tacrolimus and Cotrimaxazole remove the number of intake of tablets. Though tacrolimus is one of the most widely used medicine for organ transplant. It is the drug of choice for all type of organ transplant to inhibit organ rejection. Hence, in the present study it was decided to prepare sustain release tablet for better effect.

The sustain release tablet of Tacrolimus and Cotrimaxazole was prepared by granulation method. Various tests were performed for hardness, friability, disintegration, dissolution. Stability of the sample was determined by HPLC report, which was found to be stable graphically. Whereas drug-drug interaction and drug-polymer are not possible as mechanism of action of all three drug are different from each other.

\section{REFERENCES}

1) Zellner E et al (2016) “Complications Following Plastic Surgery in Solid Organ Transplant Recipients" Department of Surgery, Yale University School of Medicine, New Haven, CT, USA 2 Department of Surgery, University of California San Francisco, San Francisco, CA, USA.

2) Michael $\mathrm{N}$ et al (2017) "Advances in diagnostics for transplant rejection" PMCID: PMC5303063; NIHMSID: NIHMS832347; PMID: 27677432; doi: 10.1080/14737159.2016.1239530

3) "Product Information.

Sulfamethoxazole - Trimethoprim (sulfamethoxazole - trimethoprim)." SICOR Pharmaceuticals Inc, Irvine, CA.

4) Trimethoprim Sulfamethoxazole (Bactrim) (2015). Product Insert. Roche Products Pty Limited. Dee Why, NSW. 


\section{Indian Journal of Research in Pharmacy and Biotechnology (IJRPB) ISSN: 2321-5674 (Print), 2320-3471 (Online)}

CrossRef DOI: https://doi.org/10.31426/ijrpb Indexed in CAS and CABI, Impact Factor: 0.64

5) Trimethoprim Sulfamethoxazole (Septra) (2006). Product Insert. Monarch Pharmaceuticals, Inc. Bristol, TN.

6) McEvoy G.K. et al; (2002) "American Hospital Formulary Service - Drug Information".

7) Evaluations of Drug Interactions. 2nd ed. and supplements. Washington, DC: American Pharmaceutical Assn., 1976, 1978, p. 342.

8) Thomson/Micromedex. (2007) "Drug Information for the Health Care Professional”. Volume 1, Greenwood Village, CO, p. 2662

9) Johnson JF, Dobmeier ME; DICP 24 (3): 250-1 (1990)

10) National Library of Medicine's Medical Subject Headings. Tacrolimus. Online file (MeSH, 2014).

11) NIH; Daily Med. Current Medication Information for Prograf (Tacrolimus) Capsule, Gelatin Coated; Prograf (Tacrolimus) Injection, Solution (Revised: September 2013).

12) Bethesda MD. (2014) "American Society of Health-System Pharmacists; Drug Information” p. 3765.
13) Health Canada; Product Monograph for Sandoz Tacrolimus (Tacrolimus immediate release capsules), Drug Identification Number (DIN): 02416824 p3 (Revision date: 11/21/13). Available from, as of June 6, 2014

14) Sweetman S.C. (ed.) Martindale-The Complete Drug Reference. 36th ed. London: The Pharmaceutical Press, 2009., p. 1848

15) Sweetman S.C. (ed.) Martindale-The Complete Drug Reference. 36th ed. London: The Pharmaceutical Press, 2009., p. 1847

16) Tacrolimus (Prograf). Product Insert. Astellas Pharma US, Inc. Northbrook, IL. (2015).

17) Bethesda, MD et al; (2002): American Society of Health-System Pharmacists, Inc. (Plus Supplements). p. 843

18) Bethesda, MD. et. al; (2014) "American Society of Health-System Pharmacists"; Drug Information .

19) NIH; Daily Med. Current Medication Information for Prograf (Tacrolimus) Capsule, Gelatin Coated; Prograf (Tacrolimus) Injection, Solution (Revised: September 2013). 


\section{Indian Journal of Research in Pharmacy and Biotechnology (IJRPB) ISSN: 2321-5674 (Print), 2320-3471 (Online)}

CrossRef DOI: https://doi.org/10.31426/ijrpb Indexed in CAS and CABI, Impact Factor: 0.64

20) Tacrolimus (Prograf). Product Insert. Astellas Pharma US, Inc. Northbrook, IL. (2015)

21) NIH; Daily Med. Current Medication Information for Prograf (Tacrolimus) Capsule, Gelatin Coated; Prograf (Tacrolimus) Injection, Solution (Revised: September 2013).

22) Bethesda, MD. et al; (2014); "American Society of Health-System Pharmacists Drug Information". p. 3770

23) Jain AK et al; Liver Transpl 8 (9): $841-5$ (2002)

24) Capone F. et al; (2014) "Scientific World Journal". Feb 20;2014:450390]

25) Duarte et. al; used Eudragit RS 100 and RL 100 as a drug carrier. "The release behaviour of acetazolamide from the prepared microparticles was studied and most products exhibited a slower release than the single drug".

26) Kale et al; "The microspheres of eudragit S100 were found to float continuously in the acidic solution and successfully release drug in a predetermined rate".
27) Anderson E. (1949) "Endosperm mucilages of legumes: occurrence and composition". Ind Eng Chem. 1949;41:2887-2890. DOI: 10.1021/ie50480a056.

28) Andres S, Zaritzky N, Califano A. (2006) "The effect of whey protein concentrates and hydrocolloids on the texture and color characteristics of chicken sausages". Int J Food Sci Technol. 2006;41:954-961. DOI: 10.1111/j.1365-2621.2005.01152.x.

29) APEDA (2011) APEDA annual export report.

http://agriexchange.apeda.gov.in/index /product_description_32head.aspx?gco de050.Accessed June 2011.

30) Barth HG, Smith DA, Chromatogr J. (1981) "High-performance sizeexclusion chromatography of guar gum”. 1981;206:410-415. DOI: 10.1016/S0021-9673(00)82558-3. 